\begin{tabular}{cc|c}
\hline Tar. Bil. Der. & Journal of Agricultural Sciences \\
& $\begin{array}{c}\text { Dergi web sayfası: } \\
\text { www.agri.ankara.edu.tr/dergi }\end{array}$ & Journal homepage: \\
& www.agri.ankara.edu.tr/journal
\end{tabular}

\title{
Jasmonic Acid Induced Systemic Resistance in Infected Cucumber by Pythium aphanidermatum
}

\author{
Ebrahim SABBAGHa ${ }^{a}$, Seyed Kazem SABBAGH ${ }^{\mathrm{b}}$, Naser PANJEHKEH ${ }^{\mathrm{c}}$, Hamid Reza BOLOK-YAZDI ${ }^{\mathrm{c}}$ \\ ${ }^{a}$ Islamic Azad University of Zahedan, Faculty of Agriculture, Department of Agronomy, Zahedan, IRAN \\ ${ }^{\boldsymbol{b}}$ Yazd University, Faculty of Science, Department of Biology, Yazd, IRAN \\ ${ }^{c}$ University of Zabol, Faculty of Agriculture, Department of Plant Protection, Zabol, IRAN
}

\section{ARTICLE INFO}

Research Article DOI: 10.15832/ankutbd.446416

Corresponding Author: Seyed Kazem SABBAGH, E-mail: sksabbagh@yazd.ac.ir, Tel: +98 (35) 31232275

Received: 22 July 2016, Received in Revised Form: 03 March 2017, Accepted: 03 March 2017

\begin{abstract}
Damping-off disease of cucumber is one of the most destructive diseases of cucumber in worldwide. In this work, the potential of jasmonic acid (JA) for induce resistant against damping off disease was investigated. The effect of JA on activity of Polyphenol oxidase (PPO), Peroxidase (PO) and Catalase (CAT) enzymes and total phenol was assayed by spectrophotometric method. Expression level of three plant defense genes as Lipoxygenase, Cupi4 and Phenylalanine ammonia-lyase genes was analyzed using qRT-PCR method. Drop-plate method was used to assay inhibitory effect of JA on radial growth of fungi. Exogenic application of JA decreased disease severity in the infected plants but did not inhibit mycelia growth on solid medium compared to control. Our results showed that JA application substantially increased the activity of oxidative enzymes at different concentration. The highest enzyme activity was recorded after 48 hours post infection (hpi) at a concentration of $400 \mathrm{mg} \mathrm{L}^{-1}$ of JA. Gene expression analysis revealed that JA is differentially able to increase the mRNA transcripts of all tested genes at $48 \mathrm{hpi}$. The expression level of Cupi4 gene was higher than the other genes in treated plants. Induced systemic resistance by JA was mediated through an enhanced expression of ISR marker genes and increase of antioxidant enzymes activity. Based on these results, we suggest that exogenic application of JA could be considered as plant resistance inducer.

Keywords: Real-time PCR; Defensive enzymes; Elicitors; Damping-off; Gene expression; Cpui4 gene
\end{abstract}

\section{Pythium aphanidermatum ile Bulaşık Hıyarlarda Jasmonik Asitin Uyardığı Sistemik Dayanıklılık}

\section{ESER BILGISİ}

Araştırma Makalesi

Sorumlu Yazar: Seyed Kazem SABBAGH, E-posta: sksabbagh@yazd.ac.ir, Tel: +98 (35) 31232275

Geliş Tarihi: 22 Temmuz 2016, Düzeltmelerin Gelişi: 03 Mart 2017, Kabul: 03 Mart 2017

\section{ÖZET}

Çökerten hastalığı dünyanın her yerinde hıyarlarda en tahripkâr hastalıklarından biridir. Bu çalışmada, çökerten hastalığına karşı jasmonik asitin (JA) uyarılmış dayanıklılığı teşvik etme potansiyeli incelenmiştir. JA'nın polifenoloksidaz (PPO), 
peroxidaz (PO) ve katalaz (CAT) enzimlerinin aktiviteleri ve toplam fenollere etkisi spektrofotometrik yöntemle belirlenmiştir. Üç bitki savunma geninin, Lipoxygenase, Cupi4 ve Phenylalanine ammonia-lyase ifade seviyeleri qRTPCR yöntemi kullanılarak analiz edilmiştir. Mantarın dairevi gelişimine JA'nın engelleyici etkisi damlatma yöntemi kullanılarak tespit edilmiştir. JA'nın dıştan uygulanması bulaşık bitkilerdeki hastalık şiddetini azaltmasına rağmen katı ortamda misel gelişimini engellememiştir. Sonuçlarımız, farklı yoğunluklarda JA uygulamasının oksidatif enzim faaliyetini büyük oranda artırdığını göstermiştir. En yüksek enzim faaliyeti $400 \mathrm{mg} \mathrm{L}^{-1} \mathrm{JA}$ yoğunluğunda bulaştırmadan 48 saat sonra kaydedilmiştir. Gen ifadesi analizleri bulaştırmadan 48 saat sonra JA'nın bütün test edilen genlerin mRNA kopyalarını farklı da olsa artırabildiğini ortaya koymuştur. Cupi4 geninin ifade edilme seviyesi, uygulama yapılan bitkilerde, diğer incelenen genlerinkinden daha fazla bulunmuştur. JA tarafından uyarılmış sistemik dayanıklılık, ISR işaretleyici genlerinin ifade edilmesi ve antioksidan enzim faaliyetinin artışı vasıtasıyla olmuştur. Sonuçlar, JA'nın dıştan uygulanmasının bitki dayanıklılığını uyarıcı olarak kabul edilebileceğini göstermiştir.

Anahtar Kelimeler: Real-time PCR; Savunma enzimleri; Elisitörler; Çökerten hastalığı; Gen ifadesi; Cpui4 gene

(C) Ankara Üniversitesi Ziraat Fakültesi

\section{Introduction}

Damping-off disease of cucumber caused by $P$. aphanidermatum is one of the most destructive diseases of cucumber under greenhouse condition (Chaube \& Pundhir 2005). The activation of resistance responses, such as hypersensitive resistance and expression of relative-defense genes during systemic acquired resistance mechanism are mediated by a signal transduction pathway (Edreva 2004). Plant hormones play an important role in molecular signaling to enhance resistance mechanisms (Vallad \& Goodman 2004). Different antioxidant enzymes such as polyphenol oxidase (PPO) and peroxidase (PO) are involved in phenol oxidation and are correlated with mechanisms of plant defense against microbial pathogens (Zhang \& Klessig 2001; Maffei et al 2007). Jasmonic acid (JA) as a member of plant hormones, regulates plant responses to various biotic and abiotic stresses (Gundlach et al 1992). The increase of JA in infected plants with some plant pathogenic fungi has been reported, whereas in mutant plans for JA signaling, fungal growth and development were increased (Trusov et al 2009). Rhizome and seeds priming of ginger plants with synthetic analogue of phytohormones resulted in induced systemic protection against P. aphanidermatum (Ghosh \& Purkayastha 2003). The role of lipoxygenase (LOX) genes in plant defense responses indifferent plants has been investigated. Increase of Lox gene expression has been reported in several infected plants with pathogenic agents as
Pseudomonas syringae in Arabidopsis (Melan et al 1993) and in compatible and incompatible tomato lines infected with Pseudomonas syringae (Koch et al 1992). Plant defense against pathogenic agents will be affected by lignin content of plant cell wall. Phenylalanine ammonia-lyase (PAL) enzyme is involved in plant cell wall lignifications (Miedes et al 2015). Expression level of $P A L$ gene in resistant line of tomato was suppressed compared to susceptible line (Lee et al 1992). Volatile plant secondary metabolites could directly suppress growth and development of pathogens in attacked tissues. This suppression could be resulted from Lox-catalyzed reactions (Croft et al 1993). A new cDNA molecule named cucumber pathogen-induced 4 (Cupi4) has been characterized in infected cucumbers with different pathogens and after treatment with three biochemical plant resistance inducers. A high level of Cupi4 transcripts was accumulated in infected tissues and was systemically spread throughout plant (Phuntumart et al 2006). In this study the effect of JA on the radial growth of $P$. aphanidermatum, antioxidant enzymes activities, expression level of some defense related genes and disease severity in inoculated cucumber with $P$. aphanidermatum was investigated.

\section{Material and Methods}

\subsection{Infection of cucumber with P. aphanidermatum}

Seeds of the susceptible cucumber plant (cv. Es2862) were surface sterilized in 3\% chloramines 
$\mathrm{T}$ (Sigma) for 3 minutes and washed three times in sterile distilled water. Surface sterilized seeds were planted in plastic pots $(16.5 \mathrm{~cm}$ deep $\times 5.5 \mathrm{~cm}$ top diameter) containing autoclaved sand-loam-clay soil (1:2:1). After the seedling emergence, the seedlings were irrigated every three to five days, or as necessary for normal growth, with fullstrength Hoagland's solution. A standard isolate of $P$. aphanidermatum was used in this study. A piece of 7 day-old cultures from $P$. aphanidermatum growth on Corn Meal Agar (CMA, Merck) medium was used for plant inoculation at 4- to 6-leaf-stage (Chamswarng \& Cook 1985). A plague of medium colonized by the fungus was placed in the vicinity of cucumber roots. Disease severity assay was evaluated based on a 0-5 scale (Table1) (Sunwoo et al 1996).

Table1- Infection degree based on disease severity in infected cucumbers with Pythium aphanidermatum

\begin{tabular}{lll}
\hline $\begin{array}{l}\text { Infection } \\
\text { degree }\end{array}$ & Symptoms & Percentage \\
\hline 0 & No visible disease symptoms & 0 \\
1 & Leaves slightly wilted & $0-30$ \\
2 & $30-50 \%$ of entire plant diseased & $30-50$ \\
3 & $0-70 \%$ of entire plant diseased & $50-70$ \\
4 & $70-90 \%$ of entire plant diseased & $70-90$ \\
5 & Plant dead & 100 \\
\hline
\end{tabular}

\subsection{JA treatment}

Chemical treatment of plants was done with a $5 \%$ JA solution (J-2500, Sigma-Aldrich St. Louis) dissolved in $100 \%$ ethanol. Ethanol $0.1 \%$ (w $\mathrm{V}^{-1}$ ) was applied to control plants. Solution was neutralized by $\mathrm{NaOH}$ to $\mathrm{pH}$ 7.A concentration of 0 , 100,200 and $400 \mathrm{mg} \mathrm{L}^{-1}(1 \mathrm{~mL})$ were used for the treatment of plants by dropping on the surface of all leaves of 21 old-day cucumber plants (at 4- to 6leaf stage) (Anderson et al 2004). In control plants, a $10 \%\left(\mathrm{v} \mathrm{v} \mathrm{v}^{-1}\right)$ solution of ethanol in water was applied. The three replications, each consisting of six pots, were performed for each treatment (Traw \& Bergelson 2003).

\subsection{Antifungal activity assay}

Antifungal activity was assayed on PDA solid medium using drop-plate method. For this reason, 9-cm Petri dishes were inoculated with a $5 \mathrm{~mm}$ agar plug cut from the edge of one week old $P$. aphanidermatum cultures. One hundred micro liters (three drops) of JA in different concentrations were then added to the Petri dishes and then were incubated at $25 \pm 2{ }^{\circ} \mathrm{C}$. Cultures were observed daily for a week (Gavin 1957).

\subsection{Biochemical assay}

To protein extraction, a fine powder of leaf tissues prepared in liquid nitrogen was homogenized with $1 \mathrm{~mL}$ of sodium phosphate buffer $(0.1 \mathrm{M}, \mathrm{pH} 6.5)$. The homogenate was filtered and centrifuged at $6800 \mathrm{rpm}$ for $15 \mathrm{~min}$ at $4{ }^{\circ} \mathrm{C}$ (Rahman et al 2006; Abkhoo \& Sabbagh 2016). The supernatant liquids were used for the enzyme activity assay. To phenolic compound extraction, a 70\% aqueous ethanol (v $\mathrm{v}^{-1}$ ) solvent was used. Folin-Ciocalteu (Sigma) reagent was used to determine total phenolic content (Singleton \& Rossi 1965). An aliquot (1 $\mathrm{mL}$ ) of extracts was added to $9 \mathrm{~mL}$ of distilled water. One $\mathrm{mL}$ of Folin-Ciocalteu phenol reagent was added to the mixture and was shaken. After 3 minutes incubation, $10 \mathrm{~mL}$ of saturated $\mathrm{Na}_{2} \mathrm{CO}_{3}$ solution was added to the mixture. The reaction was incubated at room temperature for 60 minutes and then, the absorbance was measured at $765 \mathrm{~nm}$ using an UV-Vis spectrophotometer (Unico, USA). The Microsoft excel software was used to calculate the standard deviations and mean values. To PO enzyme activity assay, $10 \mu \mathrm{L}$ of protein extracts and $2 \mathrm{~mL}$ pyrogallol $(0.05 \mathrm{M})$ were added to $0.5 \mathrm{~mL}$ of $\mathrm{H}_{2} \mathrm{O}_{2}(1 \%)$ and were incubated at room temperature (Hammerschmidt et al 1982). To investigate PPO enzyme activity, $200 \mu \mathrm{L}$ of the protein extract was added to $1.5 \mathrm{~mL}$ of $0.1 \mathrm{M}$ sodium phosphate buffer (pH 6.5) and then $200 \mu \mathrm{L}$ of catechol (0.01 M) was added (Donovan et al 1998; Doan et al 2014) and for catalase activity assay, crude leaf extract $(10 \mu \mathrm{L})$ was added to the reaction mixture $(1 \mathrm{~mL})$ contain sodium phosphate buffer $(0.05 \mathrm{M}, \mathrm{pH} 7.0)$ and $\mathrm{H}_{2} \mathrm{O}_{2}$ in the final concentration of $10 \mathrm{mM}$ (Barka 2001). 
Absorbance changes were monitored at 240, 420 and $470 \mathrm{~nm}$ wavelengths for catalase, PO and PPO enzyme activity assay, respectively.

\section{5. $q R T-P C R$ analysis}

Expression level of Lox (F: GAGAGCGTAAG GAATGGGATAGAA; R: CACCGGGTTCGGAA AGG), PAL (F: GGTGTTCTGCGAGGTGATGA, R: AGGGTGGTGCTTCAGCTTGT) and Cupi4 (F: TCACTGTGGTGTGTGCTCTC; R: ACTCAA GCCATTGCCTTCCA) genes was analyzed using qRT-PCR method. The Actin gene (F: GAAGG AATAACCACGCTCAG; R: ACACAGTTCCCAT CTACGAG) was used as reference gene. Quantitative RT-PCR was done by using a light cycler (Corbett 3000, Australia) at $95{ }^{\circ} \mathrm{C}$ for 4 minutes, followed by denaturation at $95{ }^{\circ} \mathrm{C}$ for 20 seconds, 20 second primer annealing at $61^{\circ} \mathrm{C}$, and elongation at $72^{\circ} \mathrm{C}$ for 30 seconds in 40 cycles, with a five-minute extension at $72{ }^{\circ} \mathrm{C}$ after the final cycle. Each gene amplification was prepared in triplicate.

\subsection{Statistical analysis}

The SPSS statistical software (version 16.0) was used for data analysis. Values were expressed as mean \pm standard deviation (SD). Gene expression analysis was calculated using the Representational State Transfer (REST) method (Pfaffl 2001).

\section{Results and Discussion}

\subsection{Fungal inhibitory and disease severity}

The disease severity was reduced three days after treatment of plants with $400 \mathrm{mg} \mathrm{L}^{-1}$ concentration of JA in the presence of $P$. aphenidermatum, when compared to control. Disease reduction was not significantly different from the first to fourth days after application of $100 \mathrm{mg} \mathrm{L}^{-1} \mathrm{JA}$ compared to control plants (Table 1). The results of inhibitory growth test showed that radial growth of $P$. aphenidermatum on solid medium had not significantly affect from all concentrations of jasmonic acid (Table 2). A positive effect of methyl jasmonate (MeJA) on mycelial growth and spore germination of different necrotrophic fungi as Colletotrichum acutatum (Cao et al 2008), Alternaria alternate (Kępczyńska \& Kępczyńska 2005), or Erysiphe graminis fsp. Hordei (Schweizer et al 1993) has been reported. But, the effect of methyl jasmonate on mycelial growth of Aspergillus flavus showed that this compound did not affect mycelial growth or colony appearance (Goodrich-Tanrikulu et al 1995). The inhibitory effect of exogenous application of methyl jasmonate and JA on the mycelial growth and spore germination of soil-born fungi has not been well elucidated. These results indicate that reduce of disease severity cannot be related to direct effect of JA on fungi growth at the root surface of cucumber. Disease severity test in cucumber seedlings infected with $P$. aphanidermatum was assayed at three week after inoculation. In the control (non-treated infected cucumber), disease incidence was higher than that treated plants. The maximum reduction was recorded at a concentration of $400 \mathrm{mg} \mathrm{L}^{-1}$ of JA. Also, disease severity was significantly reduced at concentration of $100 \mathrm{mg} \mathrm{L}^{-1}$ and $200 \mathrm{mg} \mathrm{L}^{-1}$ of JA compared to control but this reduction did not significantly differ at $200 \mathrm{mg} \mathrm{L}^{-1}$ compared to $100 \mathrm{mg} \mathrm{L}^{-1}$ of JA (Table 2). Activation of jasmonate-dependent defense

Table 2- The effect of JA on disease severity (three week after inoculation) and growth rate inhibition of Pythium aphanidermatumon solid culture medium

\begin{tabular}{lll}
\hline JA concentration $\left(\mathrm{mg} \mathrm{L}^{-1}\right)$ & Disease severity** $(\%)$ & Inhibition percentage $^{*}$ \\
\hline 0 & $4^{\mathrm{a} *}$ & $1.93( \pm 0.02)$ \\
100 & $2.86^{\mathrm{b}}$ & $1.95( \pm 0.04)$ \\
200 & $2.85^{\mathrm{b}}$ & $1.85( \pm 0.06)$ \\
400 & $1.57^{\mathrm{d}}$ & $1.65( \pm 0.05)$ \\
\hline
\end{tabular}

*, each value is the mean $( \pm \mathrm{SD})$ based on 48 measurements in duplicate experiments; ${ }^{* *}$, in a column means followed by a common letter are not significantly different at the $5 \%$ level by Duncan's multiple range tests (DMRT) 
pathways in Arabidopsis thaliana plants infected with Pseudomonas syringae pv. Tomato (Pst) lead to significant reduction in disease severity (Van et al 2000). Pre-harvest application of sweet cherry fruit with methyl jasmonate $(2 \mathrm{mM})$ significantly reduced soft rot disease compared to control (Yao \& Tian 2005). Based on these data, we suggested that JA application at a high concentration (up to $400 \mathrm{mg}$ $\mathrm{L}^{-1}$ ) could decrease disease incidence via systemic acquired resistance mechanism.

\subsection{Total phenolic compounds}

Total phenolic compounds assay showed a significant increase of these compound 48 hpi upon treatment of JA at $400 \mathrm{mg} \mathrm{L}^{-1}$ concentration and then was slowly decreased at 72 hpi for all concentration of JA. For $24 \mathrm{hpi}$, there was not significant increase of phenolic compounds between JA concentrations while compared to control (Figure 1). Phenolic compounds in plant are necessary for growth and defense responses to invading pathogens. In plants, a broad range of secondary metabolites with toxic activity against pathogens are produced (Lattanzio \& Cardinali 2006). These defensive compounds can reduce disease damage only after initial time after inoculation which leads to an effective defense response (Wittstock \& Gershenzon 2002). A direct and positive relevancy between the quantity and quality of phenolic compounds and induced systemic resistance has been demonstrated in infected plants with different pathogens in the presence of resistance inducers (Elliot 1999; Amzad Hossain \& Shah 2015).

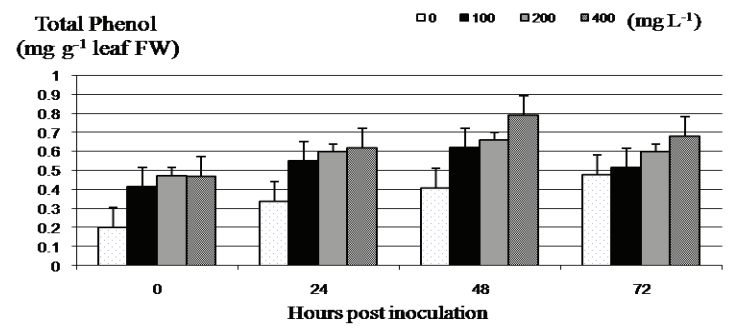

Figure 1- The effect of JA on the phenol component in infected cucumber plant with Pythium aphanidermatum

\subsection{Oxidative enzyme activity}

The polyphenol oxidase activity was increased within $3 \mathrm{~d}$ after inoculation for all JA concentrations (Figure 2), but the highest level was observed with $400 \mathrm{mg} \mathrm{L}^{-1}$. JA is as classes of plant hormones modulates oxidative enzyme activities which result to plant resistance and subsequently protect plant tissues against pathogens (Gundlach et al 1992). As shown in Figure 2, during the first day after inoculation (24 hpi), PPO activity was not increase for all JA applications. The highest level of enzyme activity was observed at a concentration of $400 \mathrm{mg}$ $\mathrm{L}^{-1}$ two days after inoculation. At $72 \mathrm{hpi}$ this rate was significantly reduced when compared to $48 \mathrm{hpi}$ (Figure 2).

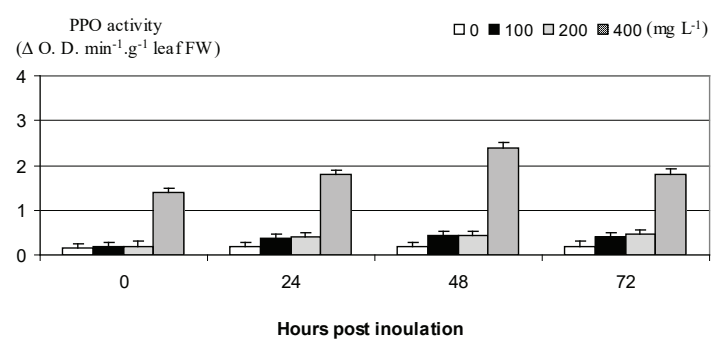

Figure 2- Change of polyphenol oxidase activity in infected cucumber with Pythium aphanidermatum under JA treatments

These results indicate the effect of JA timing to trigger defense mechanisms in infected cucumbers. Relation between PPO enzymes to wounding and enzymatic browning has been studied in a number of plants (Demir \& Kocacaliskan 2001). This enzyme plays an important role in biosynthesis of alkaloids under biotic and abiotic stress (Bilková at al 2005). Like PPO enzyme, a significant level of PO enzyme activity was recorded at a concentration of $400 \mathrm{mg}$ $\mathrm{L}^{-1}$ during the 48 hpi. A significant reduction was observed after 72 hpi in all JA concentrations but this reduction was not lower than the early days after inoculation (Figure 3). These results indicate long-term effects of JA on systemic acquired resistance. The antioxidant PO enzyme is essential for induced systemic resistance and could be used as a biomarker of induced resistance in plants for 
cell wall lignifications (Kuć 2001). In this work, JA application on infected plants showed a direct relation between disease reduction and enzyme activity. Our data showed that PO activity is enhanced in treated plants at different concentration of JA.

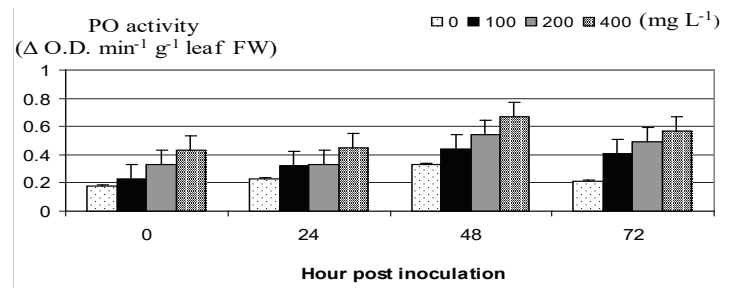

Figure 3- Peroxidase activity in infected cucumber with Pythium aphanidermatum under different JA treatment

Increase of PO activity has been resulted in number of plants associated with phytopathogenic fungi (Kruger et al 2003; Silva et al 2008) and also other biotic-elicitor as bacteria, nematode and virus. In the infected Palm trees with Fusarium oxysporum sp. albedinis, application of JA at a concentration of $50 \mu \mathrm{M}$ resulted in increase of PPO and PO activity, 1.3-2.2 times, respectively compared to non-treated plants (Jaiti et al 2009). The results of this study are in agreement with related works. A significant increase of catalase level was observed within 48 hpi for all JA concentration and then was returned to control treatment at $72 \mathrm{hpi}$. Unlike other enzyme, the highest effect of JA was noted at $200 \mathrm{ppm}$ of JA concentration resulted to increase of catalase level in infected cucumber (Figure 4). These observations indicate that low concentrations of JA could play an important role in enhancement of induced defense mechanisms. Change in oxidative enzyme activities induced by silicon application has been demonstrated in infected cucumbers with Phytophthora meloni and they showed a positive correlation between silicon concentrations and CAT enzyme activity compared to control plants (Mohaghegh et al 2011). Increase of antioxidant enzymes activity have been shown in infected wheat with Blumeria graminis f. sp. tritici, (Elliott \& Snyder 1991). The present results here are consistent with our previous study in which change in PPO and PO enzymes were increased in infected wheat with Fusarium graminearum induced by silicon (Ghazimohseni et al 2014) and infected cucumber plans with Phytopthora melonis induce by commercial extract of alga (Abkhoo \& Sabbagh 2016). A high level of induced systemic resistance in inoculated cucumbers with Pseudomonas syringe pv. syringe (a hypersensitive reaction inducer) at 24 hpi has been demonstrated (Smith et al 1991) which is in agreement with our results. Based on these results, we could conclude that JA can leads to induced systemic resistance through increase of oxidative enzymes activity especially at the initial time after infection.

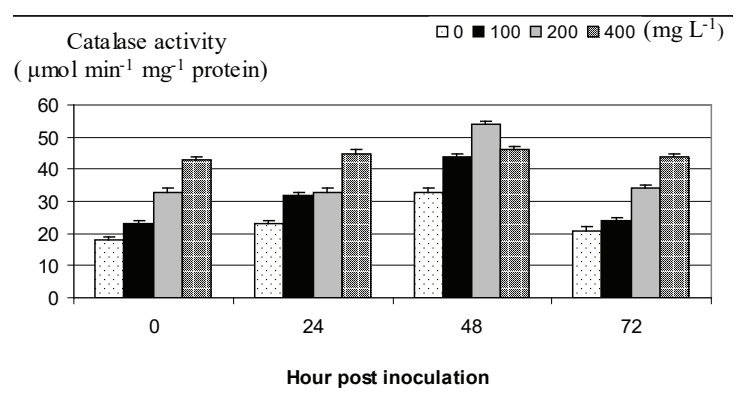

Figure 4- Catalase activity in infected cucumber by Pythium aphanidermatum treated by different JA concentration

\subsection{Gene expression analysis}

Gene expression analysis showed that the level of Loxgene in response to damping-off disease reached to a maximum level at $48 \mathrm{~h}$ post inoculation at all concentrations of JA. Quantitative real-timeRT PCR confirmed a 21-fold change of Lox gene expression in infected plants treated with JA at concentration of $400 \mathrm{mg} \mathrm{L}^{-1}$ at $48 \mathrm{~h}$ post inoculation when compared to the control treatment (Figure 5). These results indicate that over expression of Lox gene is directly dependent on pathogen stimulation at the first days post inoculation. These results indicate that a low concentration of JA is able to induce systemic acquired resistance. The decretive role of Lox genes in systemic acquired resistance and the plant defense responses to abiotic stresses such as pathogenic fungi has been demonstrated 
(Feussner \& Wasternack 2002). It has been reported that Lox genes are expressed in Arabidopsis, tomato and cucumber plants in response to exogenous application of phytohormones (Feussner \& Wasternack 2002; Liu et al 2010).

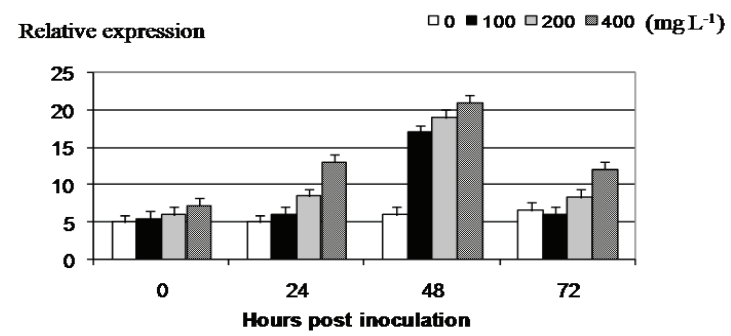

Figure 5- Expression change of Lox gene in cucumber plants under JA treatment

Expression pattern of $\mathrm{Pal}$ gene showed a high expression level at $48 \mathrm{~h}$ post inoculation for 400 $\mathrm{mg} \mathrm{L}^{-1}$ concentration (Figure 6). These observations confirm that JA plays an important role in PAL enzyme mediation which leads to increase cell wall lignifications as a physical barrier to phytopathogenic agents. Pal genes over-expression (11 putative genes for PAL synthesis) has been reported in rice plants against Magnaporthe oryzae (Giberti et al 2012). A low concentration of salicylic acid and benzothiadiazole $(\mathrm{BTH})$ resistance inducers, activated the phenylalanine ammonia-lyase (PAL) defense gene in tissue culture of parsley (Thulke \& Conrath 1998). In our study, control plants (nontreated) showed no significant increase in PAL activity while an increase of transcription rate of $\mathrm{Pal}$

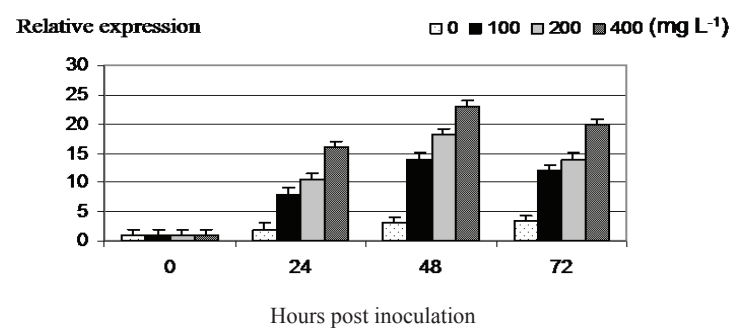

Figure 6- Expression level of $P A L$ gene in infected cucumber with Pythium aphanidermatum under JA treatments gene was found at different JA concentration during all times-points after inoculation (Figure 6). These results suggest an essential role of JA on activation and up-regulation of defense-relates genes.

The levels of Cupi4 transcripts were higher than the other tested genes in infected cucumber. Unlike other genes, high expression of Cupi4 gene was recorded at $72 \mathrm{~h}$ post inoculation (25 times) (Figure 7). These results suggest that Cupi4 might not play an important role in defense mechanisms at the early time-points of plant inoculation. The role of Cupi4 gene to induce resistance of cucumber against plant bacterial agents has been demonstrated. The mRNA transcripts of the Cupi4 gene accumulate locally in the infected cucumber leaves with Pseudomonas lachrymans at $12 \mathrm{hpi}$ and spread systemically throughout the plant leaves after 48 hpi. The antibacterial properties of Cupi4 transcripts have been suggested by finding of bacterial host cells death and high accumulation of Cupi4 mRNA in these cells (Phuntumartet al 2006). The effect of different bi-fertilizers on expression of defense-related genes in infected cucumbers with P. aphanidermatum showed a high level expression of Cupi4 mRNA transcripts (Sabbagh \& Valizadeh 2016) that is in agreement with our finding in this study. So, based on our results, Cupi4 transcripts might acts as hypersensitive reaction inducer in infected tissues of plants but not at early time points of inoculation.

Relative expression

$\square 0 \square 100 \square 200 \square 400\left(\mathrm{mgL}^{-1}\right)$

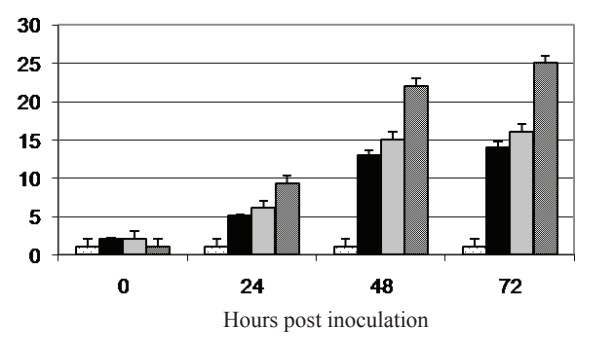

Figure 7- The effect of JA on Cupi4 gene expression at three time interval after inocuation with Pythium aphanidermatum 


\section{Conclusions}

In conclusion, the change of antioxidant enzymes due to using phyto-hormones as jasmonic acid can plays an important role to decrease of plant diseases. Improvement of plant growth under disease stress by application of phyto-hormones at the first time of inoculation could lead to disease suppression followed by systemic resistance through increase of antioxidant enzymes activities and pathogenesis related proteins. Study of different aspects of gene expression analysis such as microarray and DNA hybridization will increase insight into plant defensive mechanisms.

\section{Acknowledgements}

This work is a part of the Research project [\# 01/04/92-41138090] financially supported by the Islamic Azad University of Zahedan Branch. We express our sincerest gratitude to them for their support. We thank Mr. Javad ABKHOO for his technical support.

\begin{tabular}{|ll|}
\hline Abbreviations and Symbols \\
\hline JA & Jasmonic acid \\
PPO & Polyphenol oxidase \\
PO & Proxidase \\
Cat & Catalase \\
PAL & Phenylalanine ammonia-lyase \\
Lox & Lipoxygenase \\
Cupi4 & Cucumber pathogen-induced 4 \\
hpi & Hour post inoculation \\
FW & Fresh weight \\
\hline
\end{tabular}

\section{References}

Abkhoo J \& Sabbagh S K (2016). Control of Phytophthoramelonis damping-off, induction of defense responses, and gene expression of cucumber treated with commercial extract from Ascophyllum nodosum. Journal of Applied Phycology 28(20): 1332-1342

Amzad Hossain M \& Shah M D (2015). A study on the total phenols content and antioxidant activity of essential oil and different solvent extracts of endemic plant Merremia borneensis. Arabian Journal of Chemistry 8(1): 66-71

Anderson J P, Badruzsaufari E, Schenk P M, Manners J M, Desmond O J \& Ehlert C (2004). Antagonistic interaction between abscisic acid and jasmonateethylene signaling pathways modulates defense gene expression and disease resistance in Arabidopsis. The Plant Cell 16(12): 3460-3479

Barka E A (2001). Protective enzymes against reactive oxygen species during ripening of tomato (Lycopersicon esculentum) fruits in response to low amounts of UV-C. Functional Plant Biology 28(8): 785-791

Bilková A, Bezakova L, Bilka F \& Psenak M (2005). An amine oxidase in seedlings of Papaver somniferum L. Biologia Plantarum 49(3): 389-394

Cao S, Zheng Y, Yang Z, Tang S, Jin P, Wang K \& Wang $X$ (2008). Effect of methyl jasmonate on the inhibition of Colletotrichum acutatum infection in loquat fruit and the possible mechanisms. Postharvest Biology and Technology 49(2): 301-307

Chamswarng C \& Cook R J (1985). Identification and comparative pathogenicity of Pythium species from wheat roots and wheat-field soils in the Pacific Northwest. Phytopathology 75(7): 821-827

Chaube H \& Pundhir V (2005). Crop diseases and their management: PHI Learning Pvt. Ltd Publisher, New Delhi

Croft K P C, Juttner F \& Slusarenko A J (1993). Volatile products of the lipoxygenase pathway evolved from Phaseolus vulgaris (L.) leaves inoculated with Pseudomonas syringae pv. phaseolicola. Plant Physiology 101(1): 13-24

Edreva A (2004). A novel strategy for plant protection: Induced resistance. Journal of Cell and Molecular Biology 3(2): 61-69

Elliot J (1999). Application of antioxidant vitamins in foods and beverages. Food Technology 53: 46-48

Elliott C \& Snyder G H (1991). Autoclave-induced digestion for the colorimetric determination of silicon in rice straw. Journal of Agricultural and Food Chemistry 39(6): 1118-1119

Feussner I \& Wasternack C (2002). The lipoxygenase pathway. Annual Review of Plant Biology 53(1): 275297

Gavin J J (1957). Analytical Microbiology. II. The Diffusion Methods. Applied Microbiology 5(1): 25-33 
Ghazimohseni V, Sabbagh S K, Esmaeilzadeh Bahabadi S \& Ghorbani M (2014). Application of silicon in induction of systemic resistance against Fusarium wheat head blight diseas. Biological Control of Pest and Plant Disease 2(3): 128-137

Ghosh R \& Purkayastha R (2003). Molecular diagnosis and induced systemic protection against rhizome rot disease of ginger caused by Pythium aphanidermatum. Current Science 85(12): 1782-1786

Giberti S, Bertea C M, Narayana R, Maffei M E \& Forlani $\mathrm{G}$ (2012). Two phenylalanine ammonia lyase isoforms are involved in the elicitor-induced response of rice to the fungal pathogen Magnaporthe oryzae. Journal of Plant Physiology 169(3): 249-254

Goodrich-Tanrikulu M, Mahoney N E \& Rodriguez S B (1995). The plant growth regulator methyl jasmonate inhibits aflatoxin production by Aspergillus flavus. Microbiology 141(11): 2831-2837

Gundlach H, Muller M, Kutchan T \& Zenk M (1992). Jasmonic acid is a signal transducer in elicitor-induced plant cell cultures. Proceding Natlonal Academic Science USA 89: 2389-2393

Hammerschmidt R, Nuckles E \& Kuć J (1982). Association of enhanced peroxidase activity with induced systemic resistance of cucumber to Colletotrichum lagenarium. Physiological Plant Pathology 20(1): 73-82

Jaiti F, Verdeil J L \& Hadrami I (2009). Effect of jasmonic acid on the induction of polyphenoloxidase and peroxidase activities in relation to date palm resistance against Fusarium oxysporum f. sp. albedinis. Physiological and Molecular Plant Pathology 74(1): 84-90

Kępczyńska E \& Kępczyńska J (2005). Inhibitory effect of methyl jasmonate on development of phytopathogen Alternaria alternata (Fr.) Keissl. and its reversal by ethephon and ACC. Acta Physiologiae Plantarum 27: 491-496

Koch E, Meier B M, Eiben H-G \& Slusarenko A (1992). A lipoxygenase from leaves of tomato (Lycopersicon esculentum Mill.) is induced in response to plant pathogenic pseudomonads. Plant Physiology 99(2): 571-576

Kruger W, Szabo L \& Zeyen R (2003). Transcription of the defense response genes chitinase IIb, PAL and peroxidase is induced by the barley powdery mildew fungus and is only indirectly modulated by $\mathrm{R}$ genes. Physiological and Molecular Plant Pathology 63(3): 167-178
Kuć J (2001). Concepts and direction of induced systemic resistance in plants and its application. European Journal of Plant Pathology 107(1): 7-12

Lattanzio V M \& Cardinali A (2006). Role of phenolics in the resistance mechanisms of plants against fungal pathogens and insects. Phytochemistry: Advances in Research 661(2): 23-67

Lee S, Nazar R N, Powell D A \& Robb J (1992). Reduced PAL gene suppression in Verticillium-infected resistant tomatoes. Plant Molecular Biology 18(2): 345-352

Liu S, Liu X \& Jiang L (2010). Genome-wide identification, phylogeny and expression analysis of the lipoxygenase gene family in cucumber. Genetics and Molecular Research 10(4): 2613-2636

Maffei M E, Mithöfer A \& Boland W (2007). Insects feeding on plants: Rapid signals and responses preceding the induction of phytochemical release. Phytochemistry 68(22): 2946-2959

Melan M A, Dong X, Endara M E, Davis K R \& Ausubel F M (1993). An Arabidopsis thaliana lipoxygenase gene can be induced by pathogens, abscisic acid, and methyl jasmonate. Plant Physiology 101(2): 441-450

Miedes E, Vanholme R, Boerjan W \& Molina A (2015). The role of the secondary cell wall in plant resistance to pathogens. Frontier in Plant Science 5(358): 1-12

Mohaghegh P, Khoshgoftarmanesh A, Shirvani M, Sharifnabi B \& Nili N (2011). Effect of silicon nutrition on oxidative stress induced by Phytophthora melonis infection in cucumber. Plant Disease 95(4): 455-460

Pfaffl M W (2001). A new mathematical model for relative quantification in real-time RT-PCR. Nucleic Acids Research 29(9): e45, doi: 10.1093/nar/29.9.e45

Phuntumart V, Marro P, Métraux J P \& Sticher L (2006). A novel cucumber gene associated with systemic acquired resistance. Plant Science 171(5): 555-564

Rahman M, Sayem S, Alam M, Islam M \& Mondol A (2006). Influence of sulphur on nutrient content and uptake by rice and its balance in old Brahmapura floodplanin soil. Journal of Soil Natural 1(3): 1-10

Sabbagh S K \& Valizadeh S (2016). Effect of bio-fertilizers on greenhouse cucumber resistant to damping-off disease caused by Pythium aphanidermatum and increase of yield component. Biological Control of Pests and Plant Diseases 5(1): 111-122 
Schweizer P, Gees R \& Mosinger E (1993). Effect of jasmonic acid on the interaction of barley (Hordeum vulgare L.) with the powdery mildew Erysiphe graminis f.sp. hordei. Plant Physiology 102(2): 503511

Silva M, Guerra-Guimarães L, Loureiro A \& Nicole M (2008). Involvement of peroxidases in the coffee resistance to orange rust (Hemileiavastatrix). Physiological and Molecular Plant Pathology 72(1): 29-38

Singleton V L \& Rossi J A (1965). Colorimetry of total phenolics with phosphomolybdic phosphotungstic acid reagents. American Journal of Enology and Viticulture 16(3): 144-158

Smith J A, Hammerschmidt R \& Fulbright D W (1991). Rapid induction of systemic resistance in cucumber by Pseudomonas syringae pv. syringae. Physiological and Molecular Plant Pathology 38(3): 223-235

Sunwoo J Y, Lee Y K \& Hwang B K (1996). Induced resistance against Phytophthora capsici in pepper plants in response to DL- $\beta$-amino-n-butyric acid. European Journal of Plant Pathology 102(7): 663670

Thulke O \& Conrath U (1998). Salicylic acid has a dual role in the activation of defence $\square$ related genes in parsley. The Plant Journal 14(1): 35-42
Traw M B \& Bergelson J (2003). Interactive effects of jasmonic acid, salicylic acid, and gibberellin on induction of trichomes in Arabidopsis. Plant Physiology 133(3): 1367-1375

Trusov Y, Sewelam N, Rookes J E, Kunkel M, Nowak E \& Schenk P M (2009). Heterotrimeric G proteins mediated resistance to necrotrophic pathogens includes mechanisms independent of salicylic acid, jasmonic acid/ethylene- and abscisic acid- mediated defense signaling. The Plant Journal 58(1): 69-81

Vallad G E \& Goodman R M (2004). Systemic acquired resistance and induced systemic resistance in conventional agriculture. Crop Science 44(6): 19201934

Wittstock U \& Gershenzon J (2002). Constitutive plant toxins and their role in defense against herbivores and pathogens. Current Opinion in Plant Biology 5: 300307

Yao H \& Tian S (2005). Effects of pre- and post-harvest application of salicylic acid or methyl jasmonate on inducing disease resistance of sweet cherry fruit in storage. Postharvest Biology and Technology 35: 253-262

Zhang S \& Klessig D F (2001). MAPK cascades in plant defense signaling. Trends in Plant Science 6(11): 520527 